\title{
Where To Retire? The Tax Implications Of Geography In Retirement
}

Tim V. Eaton, Miami University, USA

Brianne Kellner, Miami University, USA

\begin{abstract}
Retirement planning is an issue of growing concern to the nation's aging population and state governments as the number of retirees continues to increase each year. Retired individuals and individuals planning for retirement should consider state tax policies, as they vary from state to state, when selecting a retirement location. State governments should also consider making tax policy changes in order to attract the older population. State tax policies could impact a retiree's financial stability during retirement. This paper examines the tax implications of geography in retirement and how relocation has the potential to significantly decrease an individual's pension income tax liability.
\end{abstract}

Keywords: Tax Implication; Retirement; Pension Income

\section{INTRODUCTION}

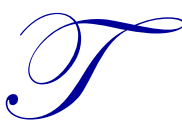

he number of individuals retiring is increasing dramatically. Financial stability after retirement should be a significant concern for many individuals who are retired or approaching retirement age. The choice of geography in retirement can have a potentially large impact on the amount of financial resources available for retirees. Additionally, the taxation of retirement income should also be an important issue for state governments who are developing tax policy as it can impact state revenues. The primary purpose of this article is to examine how state tax policies could impact retirees based on retirement location.

The United States Census Bureau estimates that there are 76.4 million baby boomers, making up $24.17 \%$ of the total US population. ${ }^{1}$ The oldest baby boomers reached the traditional retirement age of 65 in 2011 and the youngest will reach retirement age in 2029. The Pew Research Center approximates that 10,000 baby boomers will retire every day for the next 15 years. ${ }^{2}$ Exhibit 1 displays the total population growth and percentages of population 65 or older between 2005 and $2013 .{ }^{3}$ Within 8 years, there has been a $28.49 \%$ increase in the retirement population (see Exhibit 1). The United States Department of Health and Human Service's AoA (Administration on Aging) has projected the 2015 percentage of population 65 and older to rise to $14.5 \%$, the 2020 percentage to rise to $16.30 \%$, the 2025 percentage to rise to $18.2 \%$, and the 2030 percentage to rise to $19.7 \%$. This represents a significant growth in the number of people retiring each year; see Exhibit 2.

\footnotetext{
1 Just how many baby boomers are there? (n.d.). Retrieved October 17, 2014, from http://www.prb.org/Publications/Articles/2002/ JustHowManyBabyBoomersAreThere.aspx

${ }^{2}$ Baby boomers retire. (2010, December 29). Retrieved January 31, 2015, from Pew Research Center website: http://www.pewresearch.org/dailynumber/baby-boomers-retire/

${ }^{3}$ Projected future growth of the older population. (n.d.). Retrieved January 31, 2015, from Administration for Community Living website: http://www.aoa.acl.gov/Aging_Statistics/future_growth/future_growth.aspx
} 


\begin{tabular}{|c|c|c|c|}
\hline \multicolumn{3}{|c|}{ Exhibit 1 } & \% Of population 65 or older \\
\hline Year & Total Population & 65 years and over & $12.05 \%$ \\
\hline 2005 & $288,378,137$ & $34,760,527$ & $12.42 \%$ \\
\hline 2006 & $299,398,485$ & $37,191,004$ & $12.55 \%$ \\
\hline 2007 & $301,621,159$ & $37,840,558$ & $12.76 \%$ \\
\hline 2008 & $304,059,728$ & $38,812,253$ & $12.87 \%$ \\
\hline 2009 & $307,006,556$ & $39,506,648$ & $13.07 \%$ \\
\hline 2010 & $309,349,689$ & $40,433,525$ & $13.28 \%$ \\
\hline 2011 & $311,591,919$ & $41,385,026$ & $13.74 \%$ \\
\hline 2012 & $313,914,040$ & $43,140,477$ & $14.13 \%$ \\
\hline
\end{tabular}

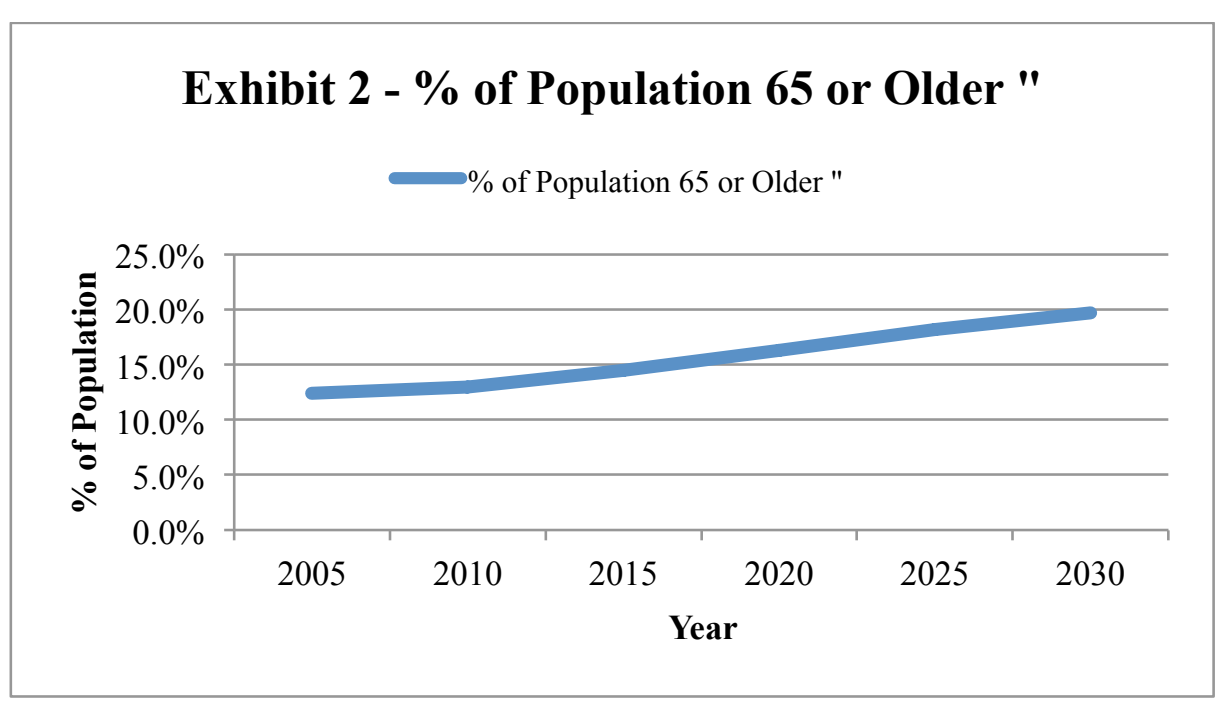

Increasing life expectancy rates present another reason why pension planning has been of growing concern. In 2000, the life expectancy rate was 76.8 years. However, the Census Bureau now expects it to rise to 78.9 years in 2015 and 79.5 years in $2020 .{ }^{4}$ The increasing life expectancy rates suggest that individuals have potentially longer retirement periods and should therefore plan for additional years of retirement income.

While there are many issues to consider, one significant factor individuals should implement into planning for financial stability during retirement is how much pension income will be retained after state taxes. All states do not have identical tax policies; therefore, where individuals choose to retire may significantly impact the amount of taxes applied to pension income. Retirees may choose to move to a different state that offers a lower tax liability.

\section{AN IMPORTANT ISSUE FOR STATE GOVERNMENTS}

The issue of differing tax policies across the nation is also an issue of consideration for states because tax policies have the power to attract new residents or encourage current residents to relocate. Several states have implemented changes in tax rates. While direct causation can be difficult to determine, tax policy changes have coincided with economic growth for some of these states. For example, some anecdotal reports suggest Maryland recently experienced an estimated loss of $\$ 1.7$ billion in tax revenues from residents relocating to states with lower tax rates. While the same report suggests Florida, a state with no income tax rate, didn't experience such losses. ${ }^{5}$ Kansas and Illinois have implemented opposite economic growth strategies. Kansas dropped its top income tax rate by $25 \%$. Contrastingly, Illinois raised its income tax rate to $5 \%$ from $3 \%$. Within a year, Kansas' GDP increased by

\footnotetext{
4 Expectation of life at birth, 1970 to 2008, and projections, 2010 to 2020. (n.d.). Retrieved October 19, 2014, from http://www.census.gov/compendia/statab/2012/tables/12s0104.pdf

${ }^{5}$ In Maryland, higher taxes chase out rich: Study. (n.d.). Retrieved September 21, 2014, from http://m.cnbc.com/us_news/48120446
} 
$1.9 \%$ compared to Illinois' GDP increase of only $0.9 \% .{ }^{6}$ Following Kansas' approach, Missouri recently passed a law that will be implemented in 2017, which will decrease the state's top individual income tax rate from $6 \%$ to $5.5 \%{ }^{7}$ California, on the other hand, is following Illinois' strategy. The state of California, which already has the highest progressive income tax rates, raised its highest tax rate from $10.3 \%$ to $13.3 \%{ }^{8}$. While there are many issues to consider, this article concentrates on pension income tax policies across the United States and how these policies may influence a taxpayer's decision when selecting a retirement location. It provides evidence on state pension tax benefits based on information from several United States documents. Individuals should also consider factors such as cost of living, median house values, heating days, and crime rates in addition to state pension income tax rates when planning for retirement.

\begin{tabular}{|c|c|c|c|}
\hline \multicolumn{4}{|c|}{ Exhibit 3} \\
\hline No State Income Tax & $\begin{array}{c}\text { Exempt All Pension } \\
\text { Income }\end{array}$ & $\begin{array}{l}\text { Partially Exempt Pension } \\
\text { Income }\end{array}$ & $\begin{array}{c}\text { No Pension Income } \\
\text { Exemption }\end{array}$ \\
\hline Alaska & Illinois & Arkansas & Alabama \\
\hline Florida & Mississippi & Colorado & Arizona \\
\hline Nevada & Pennsylvania & Delaware & California \\
\hline New Hampshire * & & Georgia & Connecticut \\
\hline South Dakota & & Hawaii & District of Columbia \\
\hline Tennessee $*$ & & Iowa & Idaho \\
\hline Texas & & Kentucky & Indiana \\
\hline Washington & & Louisiana & Kansas \\
\hline Wyoming & & Maine & Massachusetts \\
\hline & & Maryland & Minnesota \\
\hline & & Michigan & Nebraska \\
\hline & & Missouri & North Carolina \\
\hline & & Montana & North Dakota \\
\hline & & New Jersey & Rhode Island \\
\hline & & New Mexico & Vermont \\
\hline & & New York & West Virginia \\
\hline & & Ohio & Wisconsin \\
\hline & & Oklahoma & \\
\hline & & Oregon & \\
\hline & & South Carolina & \\
\hline & & Utah & \\
\hline & & Virginia & \\
\hline
\end{tabular}

\section{TAX BENEFITS VARY FROM STATE TO STATE}

State tax policies determine an individual's taxable pension income. Pension income tax policies vary from state to state. There are four broad categories that describe the different approaches states can take when taxing pension income. Exhibit 3 categorizes each state and its tax policy.

Some states do not tax any form of individual income, including pension income. These states include Alaska, Florida, Nevada, South Dakota, Texas, Washington, and Wyoming. New Hampshire and Tennessee only enforce taxes on dividends and interest. ${ }^{9}$ Illinois, Mississippi, and Pennsylvania tax individual income; yet, exempt all pension income from taxes. States that do not tax individual income or exempt all pension income from taxes are the most attractive states to retirees because income during retirement is not decreased due to taxes. The two

\footnotetext{
${ }^{6}$ A taxing tale of two states: Illinois and Kansas. (n.d.). Retrieved October 18, 2014, from http://www.forbes.com/sites/stevemoore/2014/09/27/ataxing-tale-of-two-states/

7 Tax-cut turbulence in Kan. buffets neighboring Mo. (n.d.). Retrieved October 18, 2014, from http://www.usatoday.com/story/news/ nation/2014/08/10/ kansas-tax-cuts-weigh-on-neighboring-missouri-/3850019/

${ }^{8}$ The reason for California's tax volatility: We soak the rich. (n.d.). Retrieved October 20, 2014, from http://www.latimes.com/local/la-me-captaxes-20140505-column.html

${ }^{9}$ Taxes by state. (n.d.). Retrieved October 26, 2014, from http://www.retirementliving.com/taxes-by-state
}

Copyright by author(s); CC-BY 
remaining tax policy categories are not as tax friendly to retirees. Some states partially exempt pension income from taxes, meaning a retiree's pension income will be taxed to a certain level. Arkansas, Colorado, Delaware, Louisiana, Georgia, Maine, Hawaii, Iowa, Kentucky, Maryland, Michigan, Missouri, Montana, New Jersey, New Mexico, New York, Ohio, Oklahoma, Oregon, South Carolina, Utah, and Virginia partially exempt pension income from taxes. Age and income restrictions are often applied to these exemptions, which vary from state to state. For example, Georgia residents between the ages of 62 and 64 receive a $\$ 35,000$ pension income exemption while residents 65 years old and older receive a $\$ 65,000$ pension income exemption. ${ }^{10}$ Louisiana imposes different restrictions. Residents 65 years or older may exempt up to $\$ 6,000$ of annual pension income from taxes. ${ }^{11}$ The majority of states exempt social security benefits from income taxes. Other types of exemptions include military pensions and railroad benefits. The last tax policy enforces taxes on all pension income. States that offer no tax exemptions to retirees include Alabama, Arizona, California, Kansas, Connecticut, Massachusetts, Idaho, Indiana, Minnesota, Nebraska, North Carolina, North Dakota, Rhode Island, Vermont, West Virginia, and Wisconsin. District of Columbia also taxes all pension income. ${ }^{12}$ This tax policy produces the greatest decrease in an individual's income during retirement. When considering retirement locations, individuals should compare state pension income tax policies to see how eligibility to retirement benefits varies across the nation. A state's pension income tax policy significantly impacts the amount of income individuals receive during retirement years.

Many retirees may not understand the benefits of relocating to a more tax friendly state because of the misconception that, regardless of relocating, pension income will be taxed in the state it was earned in. On January 10, 1996, President Clinton signed P.L. 104-95 to protect people's pension income. P.L. 104-95 "prohibits state taxation of certain pension income of nonresidents." If If an individual retires in a different state, the state in which the pension income was earned cannot enforce taxes on that pension. For example, P.L. 104-95 prohibits California from taxing a previous resident's pension income after relocating to another state. Another concern to retirees is only earning a fraction of pre-retirement income. Exhibit 4 compares each state's average pre-retirement income to the average income during retirement. This exhibit uses income statistics provided by the Census Bureau's American Community Survey. ${ }^{14}$

\footnotetext{
${ }^{10}$ Taxes by state. (n.d.). Retrieved October 26, 2014, from http://www.retirementliving.com/ taxes-by-state

${ }^{11}$ State-by-state guide to taxes on retirees. (n.d.). Retrieved October 26, 2014, from http://www.kiplinger.com/tool/retirement/T055-S001-stateby-state-guide-to-taxes-on-retirees/zndex.php?map=1\&state_id=19\&state=Louisiana

${ }_{12}^{12}$ Taxes by state. (n.d.). Retrieved October 26, 2014, from http://www.retirementliving.com/ taxes-by-state

${ }^{13}$ Federal statute enacted prohibition state income taxation of certain pension income of nonresidents. (n.d.). Retrieved November 7, 2014, from http://www.pmstax.com/state/bull9602.shtml

${ }_{14}$ Retirement income ample in just one state. (n.d.). Retrieved January 31, 2015, from Interest.com website: http://www.interest.com/retirementplanning/news/retirement-income-ample-in-one-state/
} 


\begin{tabular}{|c|c|c|c|c|}
\hline \multicolumn{5}{|c|}{ Exhibit 4} \\
\hline State & $\begin{array}{l}\text { Pre-Retirement } \\
\text { Income (45-64) } \\
\end{array}$ & $\begin{array}{c}\text { Retirement } \\
\text { Income }(65+)\end{array}$ & Decrease & $\begin{array}{c}\% \text { of Pre-Retirement } \\
\text { Income }\end{array}$ \\
\hline Alabama & $\$ 51,839$ & $\$ 33,469$ & $\$ 18,370$ & $64.56 \%$ \\
\hline Alaska & $\$ 81,934$ & $\$ 53,822$ & $\$ 28,112$ & $65.69 \%$ \\
\hline Arizona & $\$ 57,348$ & $\$ 39,097$ & $\$ 18,251$ & $68.18 \%$ \\
\hline Arkansas & $\$ 47,760$ & $\$ 31,959$ & $\$ 15,801$ & $66.92 \%$ \\
\hline California & $\$ 72,091$ & $\$ 43,595$ & $\$ 28,496$ & $60.47 \%$ \\
\hline Colorado & $\$ 70,732$ & $\$ 43,281$ & $\$ 27,451$ & $61.19 \%$ \\
\hline Connecticut & $\$ 84,757$ & $\$ 44,240$ & $\$ 40,517$ & $52.20 \%$ \\
\hline Delaware & $\$ 69,955$ & $\$ 43,452$ & $\$ 26,503$ & $62.11 \%$ \\
\hline District of Columbia & $\$ 64,536$ & $\$ 47,632$ & $\$ 16,904$ & $73.81 \%$ \\
\hline Florida & $\$ 54,591$ & $\$ 37,031$ & $\$ 17,560$ & $67.83 \%$ \\
\hline Georgia & $\$ 56,760$ & $\$ 37,008$ & $\$ 19,752$ & $65.20 \%$ \\
\hline Hawaii & $\$ 80,452$ & $\$ 55,560$ & $\$ 24,892$ & $69.06 \%$ \\
\hline Idaho & $\$ 56,883$ & $\$ 36,226$ & $\$ 20,657$ & $63.69 \%$ \\
\hline Illinois & $\$ 69,038$ & $\$ 38,304$ & $\$ 30,734$ & $55.48 \%$ \\
\hline Indiana & $\$ 58,692$ & $\$ 35,339$ & $\$ 23,353$ & $60.21 \%$ \\
\hline Iowa & $\$ 64,714$ & $\$ 36,690$ & $\$ 28,024$ & $56.70 \%$ \\
\hline Kansas & $\$ 63,454$ & $\$ 37,574$ & $\$ 25,880$ & $59.21 \%$ \\
\hline Kentucky & $\$ 50,482$ & $\$ 32,964$ & $\$ 17,518$ & $65.30 \%$ \\
\hline Louisiana & $\$ 52,115$ & $\$ 31,230$ & $\$ 20,885$ & $59.93 \%$ \\
\hline Maine & $\$ 54,266$ & $\$ 34,376$ & $\$ 19,890$ & $63.35 \%$ \\
\hline Maryland & $\$ 88,101$ & $\$ 49,494$ & $\$ 38,607$ & $56.18 \%$ \\
\hline Massachusetts & $\$ 82,112$ & $\$ 40,020$ & $\$ 42,092$ & $48.74 \%$ \\
\hline Michigan & $\$ 58,530$ & $\$ 36,939$ & $\$ 21,591$ & $63.11 \%$ \\
\hline Minnesota & $\$ 74,284$ & $\$ 38,531$ & $\$ 35,753$ & $51.87 \%$ \\
\hline Mississippi & $\$ 43,354$ & $\$ 29,511$ & $\$ 13,843$ & $68.07 \%$ \\
\hline Missouri & $\$ 56,337$ & $\$ 34,436$ & $\$ 21,901$ & $61.13 \%$ \\
\hline Montana & $\$ 55,727$ & $\$ 35,457$ & $\$ 20,270$ & $63.63 \%$ \\
\hline Nebraska & $\$ 64,729$ & $\$ 37,343$ & $\$ 27,386$ & $57.69 \%$ \\
\hline Nevada & $\$ 58,626$ & $\$ 41,494$ & $\$ 17,132$ & $70.78 \%$ \\
\hline New Hampshire & $\$ 78,157$ & $\$ 42,406$ & $\$ 35,751$ & $54.26 \%$ \\
\hline New Jersey & $\$ 85,778$ & $\$ 45,092$ & $\$ 40,686$ & $52.57 \%$ \\
\hline New Mexico & $\$ 52,784$ & $\$ 35,785$ & $\$ 16,999$ & $67.80 \%$ \\
\hline New York & $\$ 68,696$ & $\$ 37,769$ & $\$ 30,927$ & $54.98 \%$ \\
\hline North Carolina & $\$ 53,876$ & $\$ 34,931$ & $\$ 18,945$ & $64.84 \%$ \\
\hline North Dakota & $\$ 72,043$ & $\$ 35,293$ & $\$ 36,750$ & $48.99 \%$ \\
\hline Ohio & $\$ 59,772$ & $\$ 35,072$ & $\$ 24,700$ & $58.68 \%$ \\
\hline Oklahoma & $\$ 55,545$ & $\$ 35,005$ & $\$ 20,540$ & $63.02 \%$ \\
\hline Oregon & $\$ 60,360$ & $\$ 38,232$ & $\$ 22,128$ & $63.34 \%$ \\
\hline Pennsylvania & $\$ 64,401$ & $\$ 35,009$ & $\$ 29,392$ & $54.36 \%$ \\
\hline Rhode Island & $\$ 71,756$ & $\$ 39,577$ & $\$ 32,179$ & $55.15 \%$ \\
\hline South Carolina & $\$ 51,935$ & $\$ 35,042$ & $\$ 16,893$ & $67.47 \%$ \\
\hline South Dakota & $\$ 59,955$ & $\$ 36,354$ & $\$ 23,601$ & $60.64 \%$ \\
\hline Tennessee & $\$ 52,122$ & $\$ 34,462$ & $\$ 17,660$ & $66.12 \%$ \\
\hline Texas & $\$ 62,381$ & $\$ 37,588$ & $\$ 24,793$ & $60.26 \%$ \\
\hline Utah & $\$ 74,390$ & $\$ 44,384$ & $\$ 30,006$ & $59.66 \%$ \\
\hline Vermont & $\$ 63,980$ & $\$ 35,844$ & $\$ 28,136$ & $56.02 \%$ \\
\hline Virginia & $\$ 75,594$ & $\$ 44,440$ & $\$ 31,154$ & $58.79 \%$ \\
\hline Washington & $\$ 70,946$ & $\$ 42,287$ & $\$ 28,659$ & $59.60 \%$ \\
\hline West Virginia & $\$ 50,157$ & $\$ 31,542$ & $\$ 18,615$ & $62.89 \%$ \\
\hline Wisconsin & $\$ 64,563$ & $\$ 34,721$ & $\$ 29,842$ & $53.78 \%$ \\
\hline Wyoming & $\$ 70,585$ & $\$ 40,934$ & $\$ 29,651$ & $57.99 \%$ \\
\hline
\end{tabular}




\begin{tabular}{|c|c|c|c|c|c|c|}
\hline \multicolumn{7}{|c|}{ Exhibit 5} \\
\hline State & $\begin{array}{c}\text { Retirement } \\
\text { Income }\end{array}$ & Taxable Income & Rate & Taxes & $\begin{array}{l}\text { After-tax } \\
\text { Income }\end{array}$ & Notes* \\
\hline California & $\$ 43,595$ & $\begin{array}{l}\$ 43,595 \\
(0-7,581) @ 1 \% \\
(7,582-17,975) @ 2 \% \\
(17,976-28,370) @ 4 \% \\
(28,371-39,383) @ 6 \% \\
(39,384-43,595) @ 8 \%\end{array}$ & $8.00 \%$ & $\$ 1,697.09$ & $\$ 41,897.91$ & $\begin{array}{l}\text { No pension income } \\
\text { exemption }\end{array}$ \\
\hline Nevada & $\$ 43,595$ & $\begin{array}{l}\$ 0 \\
(43,595) @ 0 \%\end{array}$ & $0.00 \%$ & $\$ 0.00$ & $\$ 43,595.00$ & No state income tax \\
\hline Louisiana & $\$ 43,595$ & $\begin{array}{l}\$ 37,595 \\
(0-12,499) @ 2 \% \\
(12,500-37,595) @ 4 \%\end{array}$ & $4.00 \%$ & $\$ 1,253.78$ & $\$ 42,341.22$ & $\$ 6,000$ exemption \\
\hline Pennsylvania & $\$ 43,595$ & $\begin{array}{l}\$ 0 \\
(43,595) @ 0 \%\end{array}$ & $3.07 \%$ & $\$ 0.00$ & $\$ 43,595.00$ & $\begin{array}{c}\text { Exempt all pension } \\
\text { income }\end{array}$ \\
\hline
\end{tabular}

Many retirees suffer from significant decreases in annual income when retiring. Some experts believe that earning roughly $60 \%-70 \%$ of pre-retirement income is ideal for a person's financial stability during retirement. The population has to be creative and think of ways to make a smaller amount of income last longer. One solution that proves to be very helpful in aiding a retiree's financial stability is moving to a state that offers a lower tax liability. Residing in a state that enforces taxes on pension income will decrease an individual's income during retirement even more. See Exhibit 5 and Exhibit 6 for examples of how a state's tax policy affects how much pension income a person will receive during retirement.

Exhibit 5 illustrates how a California retiree's after-tax retirement income is dependent on state tax policies. The filing singly retiree's average retirement income of $\$ 43,595$, as shown in Exhibit 4, would be taxed at the 8\% marginal tax rate in California because California doesn't offer any pension income exemptions. ${ }^{15}$ The retiree in this example faces a $\$ 28,496$ decrease $(\$ 72,091$ - $\$ 43,595)$ in pre-retirement income to retirement income, as shown in Exhibit 4, and must pay $\$ 1,697.09$ in income taxes due to California's tax policy.

Moving to a state like Nevada, which doesn't tax income, or a state like Pennsylvania, which exempts all pension income from taxes, could potentially save this retiree approximately $\$ 1,697.09$ a year as compared to California. Moving to a state that exempts partial pension income from taxes, like Louisiana, could benefit this retiree. Louisiana offers a $\$ 6,000$ exemption to residents 65 years or older. ${ }^{16}$ Only $\$ 37,595$ of the pension income would be taxed at Louisiana's $4 \%$ marginal tax rate, providing an after-tax income of $\$ 42,341.22$. If this Californian moves to a state that taxes pension income similarly to Louisiana, he or she would approximately have an extra \$443.31 per year of after-tax income. There are several other factors that individuals should consider when selecting retirement locations. Some of these factors include housing prices, cost of living, heating days, etc. This article solely focuses on state pension income tax policies and how they can affect an individual's income during retirement.

\footnotetext{
${ }^{15}$ State individual income tax rates, 2000-2014. (n.d.). Retrieved November 8, 2014, from http://taxfoundation.org/article/state-individualincome-tax-rates

${ }^{16}$ State-by-state guide to taxes on retirees. (n.d.). Retrieved October 26, 2014, from http://www.kiplinger.com/tool/retirement/T055-S001-stateby-state-guide-to-taxes-on-retirees/
} 


\begin{tabular}{|c|c|c|c|c|c|c|}
\hline \multicolumn{7}{|c|}{ Exhibit 6} \\
\hline State & $\begin{array}{l}\text { Retirement } \\
\text { Income }\end{array}$ & Taxable Income & Rate & Taxes & $\begin{array}{l}\text { After-tax } \\
\text { Income }\end{array}$ & Notes* \\
\hline $\mathrm{DC}$ & $\$ 47,632$ & $\begin{array}{l}\$ 47,632 \\
(0-9,999) @ 4 \% \\
(10,000-39,999) @ 6 \% \\
(40,000-47,632) @ 8.5 \%\end{array}$ & $8.50 \%$ & $\$ 2,848.62$ & $\$ 44,783.38$ & $\begin{array}{l}\text { No pension income } \\
\text { exemption }\end{array}$ \\
\hline Florida & $\$ 47,632$ & $\begin{array}{l}\$ 0 \\
(47,632) @ 0 \%\end{array}$ & $0.00 \%$ & $\$ 0.00$ & $\$ 47,632.00$ & No state income tax \\
\hline Maryland & $\$ 47,632$ & $\begin{array}{l}\$ 20,532 \\
(0-999) @ 2 \% \\
(1,000-1,999) @ 3 \% \\
(2,000-2,999) @ 4 \% \\
(3,000-20,532) @ 4.75 \%\end{array}$ & $4.75 \%$ & $\$ 922.68$ & $\$ 46,709.00$ & $\$ 27,100$ exemption \\
\hline Illinois & $\$ 47,632$ & $\begin{array}{l}\$ 0 \\
(47,632) @ 0 \%\end{array}$ & $5.00 \%$ & $\$ 0.00$ & $\$ 47,632.00$ & $\begin{array}{l}\text { Exempt all pension } \\
\text { income }\end{array}$ \\
\hline
\end{tabular}

Exhibit 6 illustrates another example of an individual benefiting from moving to a more tax friendly state for retirement. The average individual retiring in D.C. earns $\$ 47,632$, as shown in Exhibit 4, and is taxed at the marginal tax rate of $8.50 \%$. The retiree in this example faces a $\$ 16,904(\$ 64,536-\$ 47,632)$ decrease in preretirement income to retirement income, as shown in Exhibit 4, and has to pay $\$ 2,849$ in income taxes. If this retiree were to move to a state that doesn't tax income, like Florida, or a state that exempts all pension income from taxes, like Illinois, he or she could potentially save $\$ 2,849$ a year. Moving to a state that exempts some pension income would also be beneficial. If this retiree were to relocate to Maryland, $\$ 27,100$ of pension income would be exempt from taxes ${ }^{17}$. Moving to Maryland would provide this retiree with $\$ 46,709$ of annual retirement income compared to only $\$ 44,783.38$ in D.C. Individuals experience significant reductions in annual income during retirement and struggle with appropriately adjusting their lifestyles. Retirees should compare their current state's pension income tax policy to other state's policies and consider relocating if there's an increase in after retirement income due to tax benefits.

\section{CONCLUSIONS}

There are several reasons why retirement planning is becoming of increasing concern. One fifth of the total population is expected to be 65 years or older by the year $2040 .{ }^{18}$ The number of people retiring, currently 10,000 baby boomers per day, and life expectancy rates are increasing each year. The nation's increased anxiety regarding pension planning is of growing concern to states and the aging population. A state's tax policy has the power to attract new residents or encourage current residents to relocate. Some states have made tax policy changes to attract more retirees while others have increased tax rates in an attempt to tax its way back to economic wealth. ${ }^{19}$ The growing importance of pension planning is causing the aging population to be more concerned about financial stability during retirement because they have to find a way to make a reduced annual income provide for extended years of retirement. People experience significant pay-cuts when retiring because the average after-retirement income is only a fraction of pre-retirement income. This retirement income has the possibility to decrease even more when taxes are applied. Where an individual retires affects his or her annual pension income because the nation's pension income tax policies vary from state to state. Some states are more tax friendly to retirees than others because income is either not taxed or all pension income is exempt from taxes. Other states are not tax friendly to retirees due to the lack of exemptions; therefore, all pension income is taxable. Depending on a retiree's current residential state, relocation may be beneficial in order to receive tax benefits. Relocating to a state that offers a lower tax liability has the potential to increase a retiree's income during retirement. The increasing number of retirees should

\footnotetext{
${ }^{17}$ State individual income tax rates, 2000-2014. (n.d.). Retrieved November 8, 2014, from http://taxfoundation.org/article/state-individualincome-tax-rates

${ }^{18}$ Projected future growth of the older population. (n.d.). Retrieved January 31, 2015, from Administration for Community Living website: http://www.aoa.acl.gov/Aging_Statistics/

19 A taxing tale of two states: Illinois and Kansas. (n.d.). Retrieved October 18, 2014, from http://www.forbes.com/sites/stevemoore/ 2014/09/27/a-taxing-tale-of-two-states
} 
consider state pension income tax policies when choosing a retirement location because they significantly impact a person's monetary wealth during retirement.

\section{ACKNOWLEDGEMENTS}

Both authors gratefully acknowledge EY for generously funding this research.

\section{AUTHOR INFORMATION}

Tim V. Eaton is a professor of accounting at Miami University in Oxford Ohio where he also serves as the EY Teaching Scholar. E-mail: Eatont@Miamioh.Edu (Contact author)

Brianne Kellner is an undergraduate student at Miami University and is the EY Student Scholar. 